JOAN OF ARC IN THE ENGLISH

IMAGINATION, 1429-I829 



\section{JOAN OF ARC}

IN THE

ENGLISH

I MAGINATION,

$1429-1829$

GAIL ORGELFINGER 
Library of Congress Cataloging-in-Publication

Data

Names: Orgelfinger, Gail Margaret, 1951- author.

Title: Joan of Arc in the English imagination, 1429-1829 / Gail Orgelfinger.

Description: University Park, Pennsylvania : The Pennsylvania State University Press, [2019] | Includes bibliographical references and index. Summary: "Explores representations of Joan of Arc in English culture from 1429 until the early nineteenth century, examining the factors that shaped retellings of her military successes and execution"-Provided by publisher.

Identifiers: LCCN 2018044814 | ISBN 9780271082189 (cloth : alk. paper)

Subjects: LCSH: Joan, of Arc, Saint, 1412-1431-In literature. | English Literature-History and criticism.

Classification: LCC PR153.J63 O74 2019 | DDC $820.9 / 351-\mathrm{dc} 23$

LC record available at https://lccn.loc.gov $/ 2018044814$

Copyright (C) 2019 Gail Orgelfinger All rights reserved Printed in the United States of America Published by

The Pennsylvania State University Press, University Park, PA 16802-1003

The Pennsylvania State University Press is a member of the Association of University Presses.

It is the policy of The Pennsylvania State University Press to use acid-free paper. Publications on uncoated stock satisfy the minimum requirements of American National Standard for Information Sciences-Permanence of Paper for Printed Library Material, ANSI Z39.48-1992. 
For my sister, another redoubtable Joan, and in memory of my mother. 
